OPEN ACCESS

Edited by:

Learn-Han Lee,

Monash University Malaysia Campus,

Malaysia

Reviewed by:

Atte Von Wright

University of Eastern Finland, Finland Joachim Wink

Helmholtz Centre for Infection

Research, Germany

Sheng Qin,

Jiangsu Normal University, China

*Correspondence:
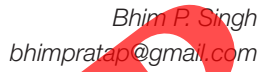

Specialty section

This article was submitted to Antimicrobials, Resistance

and Chemotherapy,

a section of the journal

Frontiers in Microbiology

Received: 10 October 2016 Accepted: 11 January 2017

Published: 25 January 2017

Citation:

Zothanpuia, Passari AK, Chandra P, Leo W, Mishra VK, Kumar B and Singh BP (2017) Production of Potent Antimicrobial Compounds from Streptomyces cyaneofuscatus

Associated with Fresh Water Sediment. Front. Microbiol. 8:68. doi: 10.3389/fmicb.2017.00068

\section{Production of Potent Antimicrobial Compounds from Streptomyces cyaneofuscatus Associated with Fresh Water Sediment}

\author{
Zothanpuia ${ }^{1}$, Ajit K. Passari', Preeti Chandra ${ }^{2}$, Vincent V. Leo ${ }^{1}$, Vineet K. Mishra', \\ Brijesh Kumar ${ }^{2}$ and Bhim P. Singh ${ }^{1 *}$ \\ 'Molecular Microbiology and Systematics Laboratory, Department of Biotechnology, Mizoram University, Aizawl, India, \\ ${ }_{2}^{2}$ CSIR-Central Drug Research Institute, Sophisticated Analytical Instrument Facility, Lucknow, India
}

The genus Streptomyces under phylum actinobacteria has been recognized as a prolific source for the production of bioactive secondary metabolites. An actinobacterial strain designated as DST103 isolated from a wetland fresh water sediment of Tamdil Lake, Mizoram, Northeast, India was identified as Streptomyees cyaneofuscatus (KY287599) using 16SrRNA gene sequencing which shares 99.87\% sequence similarity with Streptomyces cyaneofuscatus NRRL B-2570'. The strain showed broad spectrum antimicrobial activities against Gram negative bacteria (Escherichia coli MTCC 739 and Pseudomonas aeruginosa MTCC 2453), Gram positive bacteria (Micrococcus luteus NCIM 2170 and Staphylococcus aureus MTCC 96) and yeast pathogen Candida albicans MTCC 3017). The methanolic extract of the strain DST103 exhibited highest antimicrobial activity against $E$. coli $\left(\mathrm{IC}_{50}=2.10 \mu \mathrm{g} / \mathrm{mL}\right)$ and minimum activity against S. aureus $\left(I C_{50}=43.63 \mu \mathrm{g} / \mathrm{mL}\right)$. Five antibiotics [trimethoprim $(18 \mu \mathrm{g} / \mathrm{g})$, fluconazole (6 $\mu \mathrm{g} / \mathrm{g})$, ketoconazole $(18 \mu \mathrm{g} / \mathrm{g})$, nalidixic acid $(135 \mu \mathrm{g} / \mathrm{g})$, and rifampicin $(56 \mu \mathrm{g} / \mathrm{g})]$ were detected and quantified using ultra-performance liquid chromatography (UPLCESI-MS/MS). Further, biosynthetic potential genes [polyketide synthases type II, nonribosomal peptide synthetases, and aminodeoxyisochorismate synthase (phzE)] were also detected in strain DST103 which may possibly be responsible for the production of antimicrobial compounds. Additionally, gas chromatography-mass spectrometry analysis showed the presence of four volatile compounds which might be responsible for their diverse biological activity. The present study revealed the presence of bioactive compounds in strain DST103, which may be a promising resource for the discovery of novel bioactive metabolites against wide range of pathogens.

Keywords: Streptomyces cyaneofuscatus, antimicrobial activity, biosynthetic genes, GC-MS, UPLC-ESI-MS/MS

\section{INTRODUCTION}

Microbial secondary metabolites are the organic compounds having potential for the discovery of new drugs to fight against antibiotic resistance (David et al., 2014). They are increasingly required with the emergence and continued persistence of multiple drug resistant (MDR) disease causing microorganisms and still the bacterial infections remain the second leading cause of 
death worldwide (Procopio et al., 2012). To overcome this, an attempt has been made by various researchers to improve the existing antibiotics or discover the new antibiotics with improved effectiveness (Parungao et al., 2007). Among the microorganisms, phylum Actinobacteria (order - Actinomycetales), represent an outstanding and notable source for the production of new bioactive secondary metabolites including antibiotics (Stach et al., 2003; Goodfellow and Fiedler, 2010). The phylum alone is accounting for the production of an approximately $75 \%$ of the total bioactive compounds including antibiotics with more than $70 \%$ produced by member of the genus Streptomyces (Berdy, 2005; Das et al., 2010; Subramani and Aalbersberg, 2012). Genus Streptomyces remains prolific producers of novel compounds with a variety of biological activities including antimicrobial, anti-cancer agents and other pharmaceutically useful compounds (Berdy, 2005; Kim et al., 2008; Saurav and Kannabiran, 2012; Wang et al., 2013; Rajan and Kannabiran, 2014; Ser et al., 2015). They are widely distributed in various ecosystems like soils, fresh waters, marine environments and lakes (Goodfellow and Williams, 1983). A continuous screening of potential bacterial taxa for secondary metabolite production is crucial for the discovery of novel compounds (Lazzarini et al., 2000).

Bio-prospecting studies on actinobacteria are mostly confined to the terrestrial and marine ecosystems and less significance has given to fresh water systems (Radhika et al., 2011). However, there are few reports about the presence of actinobacteria from fresh water ecosystems worldwide (Sibanda et al., 2010; Radhika et al., 2011; Saravanan et al., 2015) where they play an important role in carbon cycle and degradation of recalcitrant organic matter (Kuznetsov, 1970). At present, there is a significant decline in discovering novel bioactive compounds from terrestrial actinobacteria (Alvan et al., 2011) which signified the needs to search for biologically active compounds from such alternative sources like fresh water resources.

In recent years, an attempt has been made by many researchers in search of new antibiotics from different unexplored habitats (Mitra et al., 2008; Goodfellow and Fiedler, 2010). Investigation of antimicrobial secondary metabolites producing actinobacteria from various ecosystems of Northeast India is reported by a number of researchers (Talukdar et al., 2012; Sharma et al., 2014, 2016; Passari et al, 2015; Zoh hanpuia et al., 2015). After literature review, Tamdil, a fresh water lake of Mizoram, North east India, which is one of the 115 wetlands in India has been found unexplored ecosystem for actinobacterial research. Even though this lake was reported earlier (Zothanpuia et al., 2016) as a significant source for bacterial isolation.

In this perspective the present study was carried out that resulted in the selection of a promising Streptomyces strain DST103 from the fresh water sediment samples of wetland, Tamdil lake Mizoram, India. The present study is intended to examine the antimicrobial biosynthetic potential of Streptomyces cyaneofuscatus against various Gram positive and Gram negative bacterial pathogens, to detect the genes (PKSII, NRPS and $p h z \mathrm{E})$ responsible for it, to characterize antibiotic production using ultra-performance liquid chromatography (UPLC-ESI$\mathrm{MS} / \mathrm{MS}$ ) and to determine the volatile compounds by using Gas chromatography-mass spectrometry (GC-MS).

\section{MATERIALS AND METHODS}

\section{Sample Collection}

Water sediment samples were collected from a wetland, fresh water Tamdil Lake $\left(23^{\circ} 44^{\prime} \mathrm{N}\right.$; $\left.92^{\circ} 57^{\prime} \mathrm{E}\right)$ of Mizoram, India during the month of May 2013. Samples were stored in a sterile screw capped tube and brought into Molecular Microbiology and Systematic Laboratory, Department of Biotechnology, Mizoram University. The samples were preserved at $4^{\circ} \mathrm{C}$ till it was processed.

\section{Isolation and Enumeration of Actinobacteria}

Actinobacteria were isolated by serial dilution and spread plate technique in eight different media [Starch Casein Agar (SCA), Yeast Extract Malt Extract Agar (ISP2), Actinomycetes Isolation Agar (AIA), Streptomyces Agar (SA), Glycerol Aspargine agar (ISP5), Tyrosine agar medium (ISP7), Tap water Yeast Extract Agar (TWYE), Trypticase soya agar (TSA)]. Serial dilution was performed by preparing stock solution with $\mathrm{mL}$ of water sediment sample and $10 \mathrm{ml}$ of sterile distilled water in a test tube and agitated for $10 \mathrm{~min}$. The suspension was serially diluted up to dilutions of $10^{-3}$ and spread on different media supplemented with cycloheximide $(30 \mu \mathrm{g} / \mathrm{ml})$ to inhibit fungal growth and nalidixic acid $(30 \mu \mathrm{g} / \mathrm{ml})$ to inhibit the growth of Gram negative bacteria. Plates were incubated at $28^{\circ} \mathrm{C}$ for 14 days and the pure culture of isolates were preserved on $20 \%$ glycerol and on their respective slant at $4^{\circ} \mathrm{C}$ for further studies.

\section{Phenotypic Characterization of Actinobacterial Isolates}

The isolates were characterized after 14 days of incubation at $28^{\circ} \mathrm{C}$. The cultural characteristics such as color of aerial and substrate mycelium, characteristics of the colony, color, and morphology of the spore chain and diffusible pigments production were studied (Goodfellow and Haynes, 1984). The purified strains were analyzed and identified as described in the International Streptomyces Project (ISP) (Shirling and Gottlieb, 1966). Using oil immersion microscope, the mycelium structures was observed and the organism was identified according to Bergey's Manual of Determinative Bacteriology, 9th edition. The spore chain morphology and ornamentation of the selected potential strain was also analyzed by field emission gun- scanning electron microscope (FEG-SEM) (Passari et al., 2016).

\section{Evaluation of Antimicrobial Activity of Actinobacterial Isolates}

Antimicrobial screening of actinobacterial isolates were performed against five pathogenic bacteria such as Gram positive bacteria, Staphylococcus aureus MTCC-96, Bacillus subtilis NCIM-2097, and Micrococcus luteus NCIM-2170; Gram negative bacteria viz., Pseudomonas aeruginosa MTCC-2453, Escherichia coli MTCC-739 and yeast Candida albicans MTCC-3017. All the pathogens were obtained from Microbial Type Culture Collection (MTCC), Chandigarh, and National Collection of Industrial Microorganisms (NCIM), Pune, India and maintained 
in the Laboratory. The bacteria and yeast strains were cultured in nutrient agar medium and Sabouraud dextrose medium at $37^{\circ} \mathrm{C}$ and $25^{\circ} \mathrm{C}$, respectively. A single pure colony of actinobacterial isolates were inoculated in tryptone yeast extract broth (ISP1) and incubated at $28^{\circ} \mathrm{C}, 150 \mathrm{rpm}$ for $7-15$ days. The grown cultures were centrifuged at $8,000 \mathrm{rpm}$ for $5 \mathrm{~min}$ and the supernatant was used for antimicrobial activity by agar well diffusion method (Saadoun and Muhana, 2008). Bacterial pathogens were spread on LB modified agar plate, and $6 \mathrm{~mm}$ diameter wells were prepared by using sterile cork borer. In each well, $70 \mu \mathrm{l}$ clear actinobacteria cell free supernatant was dispensed, and the plates were incubated at $37^{\circ} \mathrm{C}$ for $24 \mathrm{~h}$. The antimicrobial activities of the isolates were determined by measuring the inhibition zone around each well. All experiments were performed in triplicates and mean was calculated.

\section{Molecular Identification and Phylogenetic Analysis \\ Genomic DNA Isolation and 16S rRNA Gene Amplification}

Genomic DNA of selected strain was extracted using In-vitrogen DNA isolation kit (K182002) following the manufacturer's protocol. The DNA quantity was checked at 260/280 using spectrophotometer (Thermo scientific Multiskan GO microplate reader). PCR amplification of $16 \mathrm{~S}$ rRNA gene was carried out using universal bacterial primers PA (5'- AGAG TTTGATCCTGGCTCAG $\left.-3^{\prime}\right)$ as forward primer and $\mathrm{PH}$ ( $5^{\prime}$ - AAGGAGGTGATCCAGCCGCA - $3^{\prime}$ ) as reverse primer (Weisburg et al., 1991). Reaction was performed on Veriti thermal cycler (Applied Biosystem, Singapore) in a total volume of $25 \mu \mathrm{l}$ containing $50 \mathrm{ng}$ of template DNA, $10 \mathrm{pmol}$ of each primer, $2.5 \mathrm{mM}$ of dNTPs, 1X PCR buffer with $1.5 \mathrm{mM} \mathrm{MgCl}_{2}$, $1 \mathrm{U} / \mu \mathrm{l}$ of Taq DNA polymerase. Reaction was performed under following conditions: initial denaturation at $95^{\circ} \mathrm{C}$ for $4 \mathrm{~min}$, followed by 30 cycles of denaturation at $94^{\circ} \mathrm{C}$ for $30 \mathrm{~s}$, annealing at $57.5^{\circ} \mathrm{C}$ for $40 \mathrm{~s}$ and extension at $72^{\circ} \mathrm{C}$ for $1.3 \mathrm{~min}$ with final extension step at $72^{\circ} \mathrm{C}$ for 10 min. A negative control reaction mixture (without DNA template) was also included with each set of PCR reactions. The amplified PCR product was checked using $1.3 \%$ agarose gel electrophoresis using TAE buffer. The PCR bands were analyzed under UV light and documented using a Bio Rad Gel Doc XR ${ }^{+}$system (Hercules, CA, USA). The PCR products of $16 \mathrm{~S}$ rRNA gene was purified by quick PCR purification kit (In-vitrogen) and sequencing was done commercially at SciGenome Pvt. Ltd. Cochin, India.

\section{Phylogenetic Analysis Based on 16S rRNA Gene Sequences}

DNA sequences were compared with the sequences retrieved from NCBI database by using BLASTn search tool (Tamura et al., 2011). Type strains of top fifteen sequences with highest scores were retrieved from EzTaxon database (Kim et al., 2012) and multiple sequence alignment was performed using the Clustal W software packaged in MEGA 6.0 (Thompson et al., 1997). The evolutionary models were selected based on the lowest Bayesian Information Criterion (BIC) scores and highest
Akaike Information Criterion (AIC) values using MEGA 6.0 (Saitou and Nei, 1987). Phylogenetic tree was constructed by neighbor joining method using MEGA 6.0 software with Tamura 3 parameters model $(R=1.25)$ (Saitou and Nei, 1987; Tamura et al., 2011), using E. coli as an out group. The significance of the branching order was determined by bootstrap analysis of 1000 replicates using $p$-distance model (Felsenstein, 1985). The obtained nucleotide sequence of the 16S rRNA gene of the potential strain was deposited in NCBI GenBank and trees were analyzed and checked using program FigTree 1.3.1.

\section{Methanolic Extraction of Potential Isolates and Antimicrobial Assay}

The selected isolate was grown in tryptone yeast extract (ISP1) broth at $28^{\circ} \mathrm{C}$ for 30 days and the culture filtrate was used for the extraction using methanol 1:1 ratio (v/v). Methanol extract was prepared in different concentrations $(100,25,500$, and $1000 \mu \mathrm{g} / \mathrm{ml}$ ) with $10 \%$ dimethyl sulphoxide (DMSO) and used for antimicrobial activity following agar well diffusion method (Saadoun and Muhana, 2008; Gebreyohannes et al,, 2013).

\section{Determination of Minimum Inhibitory Concentration (MIC) of Potential Isolates}

Minimum inbibitory concentration (MIC) of selected strain was determined by following broth mícro dilution technique using 96-well microtiter plate (Eloff, 1998). Crude extract of the selected strain was prepared with $10 \%$ DMSO in different concentrations $(100,25,500$, and $1000 \mu \mathrm{g} / \mathrm{ml})$. The bacterial pathogens were grown up to a fmal concentration of $1.0 \times 10^{-4} \mathrm{CFU} / \mathrm{mL}$ $(O D=0.402)$. Different concentrations of the crude extract were added in 96-well microtiter plate containing a bacterial culture as test and without bacterial culture as controls. Antibiotic ampicillin, $0.01 \mu \mathrm{g} / \mathrm{ml}$ ) along with bacterial cultures were used as positive control, DMSO containing bacterial cultures were used as negative control. The plates were incubated at $37^{\circ} \mathrm{C}$ for $36 \mathrm{~h}$ and absorbance was taken at $620 \mathrm{~nm}$ in spectrophotometer UV-VIS (MultiscanTM GO, Thermo Scientific, MA, USA). IC 50 was expressed as the concentration $(\mu \mathrm{g} / \mathrm{ml})$ of crude extract at which $50 \%$ of bacterial growth was inhibited and was calculated using the calibration curve by linear regression.

\section{Detection of Antibiotics using Ultra-Performance Liquid Chromatography (UPLC-MS/MS) Preparation of Standard Solution}

Mixed stock solution containing standard antibiotics (trimethoprim, fluconazole, ketoconazole, nalidixic acid, and rifampicin) were prepared in methanol. Mixed standards were diluted with methanol within the ranges from 0.5 to $500 \mathrm{ng} / \mathrm{mL}$ to prepare the working standard solution used for plotting calibration curve. The standard stock and working solutions were all stored at $-20^{\circ} \mathrm{C}$ until use and vortexed prior to injection.

\section{Instrumentation and Analytical Conditions}

An acquity ultra-performance liquid chromatography (UPLC ${ }^{\mathrm{TM}}$ ) system consisting of autosampler and a binary pump (Waters, 
Milford, MA, USA) was used for analysis. Compounds were separated using an acquity BEH C18 $(2.1 \mathrm{~mm} \times 50 \mathrm{~mm}, 1.7 \mu \mathrm{m}$; Waters, Milford, MA, USA) analytical column. The mobile phase consisted of two solvents: $0.1 \%(\mathrm{v} / \mathrm{v})$ formic acid in water (A) and acetonitrile (B) with the gradient program performed of a linear increase from 0 to $1 \mathrm{~min}, 12-90 \% \mathrm{~B} ; 2-4 \mathrm{~min}, 90-95 \% \mathrm{~B} ; 4-5 \mathrm{~min}$, $95-12 \% \mathrm{~B}, 1 \mathrm{~min}$ post-run and $12 \% \mathrm{~B}$. The flow rate was set at $0.35 \mathrm{ml} / \mathrm{min}$ with injection volume $5 \mu \mathrm{l}$. UPLC system coupled to triple-quadrupole linear ion trap mass spectrometer (API 4000 QTRAP ${ }^{\mathrm{TM}}$ MS/MS system from AB Sciex, Concord, ON, Canada) having electro spray (Turbo $\mathrm{V}^{\mathrm{TM}}$ ) ion source was run in positive and negative ionization mode. The following optimized parameters were used for positive control: ion spray voltage (5500 $\mathrm{V})$; turbo spray temperature $\left(450^{\circ} \mathrm{C}\right)$; heater gas (gas 2, $50 \mathrm{psi}$ ); nebulizer gas (gas 1, 50 psi); collision gas (medium); curtain gas (20 psi). The mass spectrometric conditions was optimized by injecting 100 to $500 \mathrm{ng} / \mathrm{ml}$ solutions of each analytes at $10 \mu \mathrm{l} / \mathrm{min}$ using a Harvard '22' syringe pump (Harvard Apparatus, South Natick, MA, USA). For each compound, highest profusion of precursor-to-product ions was selected for MRM quantitation. Data acquisition and instrument control were done by Analyst (1.5.1 software package, AB Sciex). The spectra enclosed the range from m/z 100 to 1000 for analysis of full scan ESI-MS. Flow injection analysis was used to optimized all the MS parameters for reference analytes such as precursor ion (Q1), product ion (Q3), entrance potential, declustering potential, cell exit potential and collision energy in positive and negative ESI mode. MRM parameters were optimized to attain the most copious, specific and stable MRM transition for every compound (Table 1).

\section{Detection and PCR Amplifications of Biosynthetic Gene Fragments (PKSIl, NRPS and phzE):}

The potential antimicrobial isolates were subjected for the amplification of genes for Polyketide synthase type II (PKS II), aminodeoxyisochorismate synthase $(p h z \mathrm{E})$ and non-ribosomal peptide synthetase (NRPS). The following degenerate primers (Table 2) were used for amplification and detection of PKSII, phzE and NRPS gene fragments according to Yuan et al. (2014) with some modifications. The action was carried out in the Veriti thermal cycler (Applied Biosystems, Singapore) under the following conditions.

PKS II $(50 \mu \mathrm{L}): 3 \mu \mathrm{L}$ template, $5 \mu \mathrm{L} 10 \times$ buffer, $1 \mu \mathrm{L} \mathrm{MgCl}_{2}$ (25 mM), $1 \mu \mathrm{L}$ DMSO (10\%), $5 \mu \mathrm{L}$ dNTP $(2.5 \mathrm{mM}), 1.8 \mu \mathrm{L}$ each primer $(10 \mu \mathrm{M})$ and $5 \mathrm{U}$ Taq DNA polymerase; $5 \mathrm{~min}$ at $95^{\circ} \mathrm{C}$, followed by 35 cycles of $1 \mathrm{~min}$ at $95^{\circ} \mathrm{C}, 1 \mathrm{~min} 30 \mathrm{~s}$ at $58^{\circ} \mathrm{C}$ and $2 \mathrm{~min}$ at $72^{\circ} \mathrm{C}$, followed by a $10 \mathrm{~min}$ extension at $72^{\circ} \mathrm{C}$.

NRPS $(50 \mu \mathrm{L}): 3 \mu \mathrm{L}$ template, $5 \mu \mathrm{L} 10 \times$ buffer, $1 \mu \mathrm{L} \mathrm{MgCl}_{2}$ (25 mM), $1 \mu \mathrm{L}$ DMSO (10\%), $5 \mu \mathrm{L}$ dNTP $(2.5 \mathrm{mM}), 2 \mu \mathrm{L}$ each primer $(10 \mu \mathrm{M})$ and $5 \mathrm{U}$ Taq DNA polymerase; $5 \mathrm{~min}$ at $95^{\circ} \mathrm{C}$, followed by 35 cycles of $1 \mathrm{~min}$ at $95^{\circ} \mathrm{C}, 2 \mathrm{~min}$ at $59^{\circ} \mathrm{C}$ and $4 \mathrm{~min}$ at $72^{\circ} \mathrm{C}$, followed by $10 \mathrm{~min}$ extension at $72^{\circ} \mathrm{C}$.

phzE $(25 \mu \mathrm{L}): 2 \mu \mathrm{L}$ template, $2.5 \mu \mathrm{I} 10 \times$ buffer with $15 \mathrm{mM}$ $\mathrm{MgCl}_{2}, 2 \mu \mathrm{L}$ BSA (1 mg/mL), $2 \mu \mathrm{L}$ dNTP $(2.5 \mathrm{mM}), 0.8 \mu \mathrm{L}$ each primer $(10 \mu \mathrm{M})$ and $20 \mathrm{Taq}$ DNA polymerase; $4 \mathrm{~min}$ at $94^{\circ} \mathrm{C}$, followed by 35 cycles of $1 \mathrm{~min}$ at $94^{\circ} \mathrm{C}, 1 \mathrm{~min}$ at $55^{\circ} \mathrm{C}$ and $2 \mathrm{~min}$ at $72^{\circ} \mathrm{C}$, followed by 28 min extension at $72^{\circ} \mathrm{C}$.

A Reaction mixture without DNA template of actinobacteria was also incorporated with each set of PCR as negative control. PCR products were visualized under gel documentation system. The PCR products of PKS $\mathrm{H}, \mathrm{NRPS}$ and $p h z \mathrm{E}$ were purified and sequenced commercially at Sci Genome Pvt. Ltd. Cochin, India.

\section{Gas Chromatography Mass}

\section{Spectroscopy (GC-MS) Analysis of Strain} DST103

The chemical compounds present in the selected strain was analyzed and identified using GC-MS as described by Ser et al. (2015) and Sharma et al. (2016) with some modifications. Crude extract of the strain was dissolved in spectroscopy-grade methanol. GC-MS analysis was performed on Perkin Elmer

\begin{tabular}{|c|c|c|c|c|c|c|c|c|}
\hline Analytes & & Q1 & Q3 & Ion species & DP & EP & CE & CXP \\
\hline Trimethoprim & & 291.2 & 231.2 & {$[\mathrm{M}+\mathrm{H}]^{+}$} & 149 & 6 & 33 & 10 \\
\hline Fluconazole & 1.07 & 307.1 & 220.1 & {$[\mathrm{M}+\mathrm{H}]^{+}$} & 59 & 10 & 27 & 8 \\
\hline Ketoconazole & 1.46 & 532.1 & 82 & {$[\mathrm{M}+\mathrm{H}]^{+}$} & 106 & 10 & 68 & 10 \\
\hline Nalidixic acid & 1.58 & 233.1 & 215.1 & {$[\mathrm{M}+\mathrm{H}]^{+}$} & 49 & 8 & 21 & 8 \\
\hline Rifamycin & 1.83 & 823.5 & 791.4 & {$[\mathrm{M}+\mathrm{H}]^{+}$} & 53 & 9 & 24 & 19 \\
\hline
\end{tabular}

TABLE 2 | Primer sets used for the amplification of secondary metabolite biosynthetic genes.

\begin{tabular}{|c|c|c|c|}
\hline Gene & Primer & Length (bp) & Reference \\
\hline PKS II (KS1F, KS1R) & $\begin{array}{l}\text { 5'-TSGCSTGCTTGGAYGCSATC-3' } \\
\text { 5'-TGGAANCCGCCGAABCCTCT-3' }\end{array}$ & 554 & Wawrik et al., 2005 \\
\hline phzE (phzEf, phzEr) & $\begin{array}{l}\text { 5'-GAAGGCGCCAACTTCGTYATCAA-3' } \\
\text { 5'-GCCYTCGATGAAGTACTCGGTGTG-3' }\end{array}$ & 450 & Schneemann et al., 2011 \\
\hline NRPS (A3F, A7R) & $\begin{array}{l}\text { 5'-GCSTACSYSATSTACACSTCSGG-3' } \\
\text { 5'-SASGTCVCCSGTSGCGTAS-3' }\end{array}$ & 700 & Ayuso-Sacido and Genilloud, 2005 \\
\hline
\end{tabular}


Turbo mass with single quadrupole fitted with PE-5MS column (length $30 \mathrm{~m}$, thickness $0.25 \mu \mathrm{m}$, internal diameter $25 \mathrm{~mm}$ ). The oven temperature was started at $75^{\circ} \mathrm{C}$ held for $5 \mathrm{~min}$ and ramped at $10^{\circ} \mathrm{C}$ per min up to $280^{\circ} \mathrm{C}$ and held for $10 \mathrm{~min}$. One microliter of the sample was injected at $250^{\circ} \mathrm{C}$ using helium as carrier gas, split at the ratio of 1:30. Mass Spectrometer was run in the electron ionization (EI) mode in $220^{\circ} \mathrm{C}$ at $70 \mathrm{eV}$ with a scan range of 10 to $620 \mathrm{~m} / \mathrm{z}$. The peaks were analyzed and identified by matching the mass spectra with the National Institute of Standards and Technology (NIST, USA) library.

\section{Phylogenetic Analysis Based on Biosynthetic Genes Sequences}

Amino acid sequences of PKS type II, NRPS and phzE genes were compared with the sequences obtained from NCBI GenBank with the BLASTp algorithm and aligned using Muscle software packaged in MEGA 6.0 (Edgar, 2004). The evolutionary models were selected based on the lowest Bayesian Information Criterion (BIC) score values using MEGA 6.0 (Saitou and Nei, 1987). All positions containing gaps and missing data were removed from the phylogenetic analysis. Maximum likelihood (ML) phylogenetic tree for PKS type II and NRPS gene were constructed using WAG model whereas Jones Taylor Thomton (JTT model) was used for constructing ML phylogenetic tree for phzE gene (Saitou and Nei, 1987).

\section{Statistical Analysis}

The antimicrobial assay was performed in triplicate process and repeated for three times. Readings was taken as the mean \pm standard deviation of mean of three replicates calculated using Microsoft Excel XP 2010. One way analysis of variance (ANOVA) was employed to test the significant differences $(P \leq 0.05)$ between antimicrobial activities of different isolates using SPSS software version 20.0.

\section{RESULTS}

Isolation and Characterization of Actinobacterial Strains

A total of 50 strains of actinobacteria were isolated from fresh water sediment samples collected from Tamdil Lake of Mizoram,
Northeast India. All the obtained isolates were purified and identified based on morphological characteristics after two to three weeks of incubation on different media. Most of the isolates showed strain specific morphological characters such as slow growth, color of mycelia from yellow, brownish white to blackish white, while, some isolates formed brown colored pigments on the media (Figure 1A). The field emission gun-scanning electron microscopy (FEG-SEM) analysis revealed that the aerial mycelia produced spore chains that were spiral and long (Figure 1B).

\section{Evaluation of Antimicrobial Activity}

The isolated actinobacterial isolates were evaluated for their in vitro antimicrobial activity against five bacterial pathogens: S. aureus, M. luteus, B. subtilis, P. aeruginosa, E. coli, and yeast C. albicans. From a total of 50 isolates tested, 10 isolates showed positive antibacterial activity against at least 3 of the tested 6 pathogens (Supplementary Table S-1). The isolate DST103 showed positive activity against 5 tested pathogens, which was indicated by its activity (15 mim inhibition diameter) against E. coli followed by C. albicans $(12.6 \mathrm{~mm})$, B. subtilis $(11.2 \mathrm{~mm})$, $P$. aeruginosa $(8 \mathrm{~mm}), S$, aureus $(7 \mathrm{~mm})$ and relatively no activity against $M$. luteus (Table 3). All the isolates showed positive activity against $E$. coli, while most of the isolates were susceptible to $S$. aureus and M. luteus. Isolate DST103 having a broad spectrum antimicrobial activity was selected for further investigations (Figure 1C).

\section{Characterization and Phylogenetic Affiliation of Isolate DST103}

Selected isolate DST103 was subjected to amplification of partial $16 \mathrm{~S}$ rRNA gene and the obtained sequence (1404 bp) having an average G+C content of $58.4 \%$ was identified as Streptomyces cyaneofuscatus (NCBI GenBank accession number KY287599) which shares $99.87 \%$ sequence similarity with Streptomyces cyaneofuscatus NRRL B-2570 ${ }^{\mathrm{T}}$. The sequence was aligned by the BLAST analysis tool along with the type strains retrieved from EzTaxon databases. Phylogenetic tree was constructed to check the unique molecular taxonomic position of the strain based on neighbor joining method with Tamura 3parameter model according to lowest BIC values using Mega 6.0. Gaps were treated by pair wise deletion and the estimated

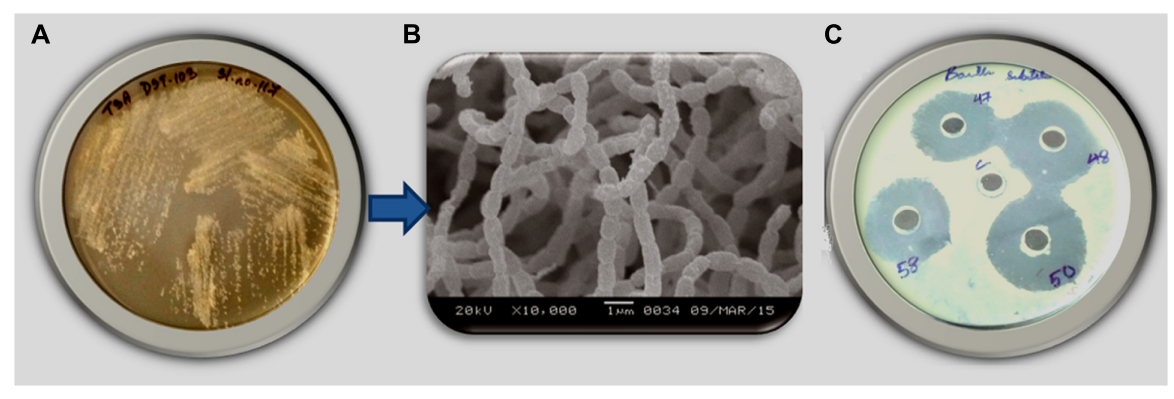

FIGURE 1 | (A) Morphological appearance of Strain DST103 on TSA medium after three weeks of incubation; (B) field emission gun- scanning electron microscope (FEG-SEM) analysis showing spore chain morphology of Strain DST103; (C) Antibacterial activity of Strain DST103 against bacterial pathogen Bacillus subtilis. 
TABLE 3 | Antimicrobial activity of strain DST103 against selected pathogens.

\begin{tabular}{lccccc}
\hline Strain no. & \multicolumn{4}{c}{ Antimicrobial activity Zone of inhibition [mean (mm) \pm SD] } \\
\cline { 2 - 5 } & S. aureus & E. coli & P. aeruginosa & B. Subtilis & M. Iuteus \\
\hline DST103 & $07.0 \pm 0.10$ & $15.0 \pm 0.03$ & $08.0 \pm 0.25$ & $11.2 \pm 0.10$ & $00.00 \pm 0.0$
\end{tabular}

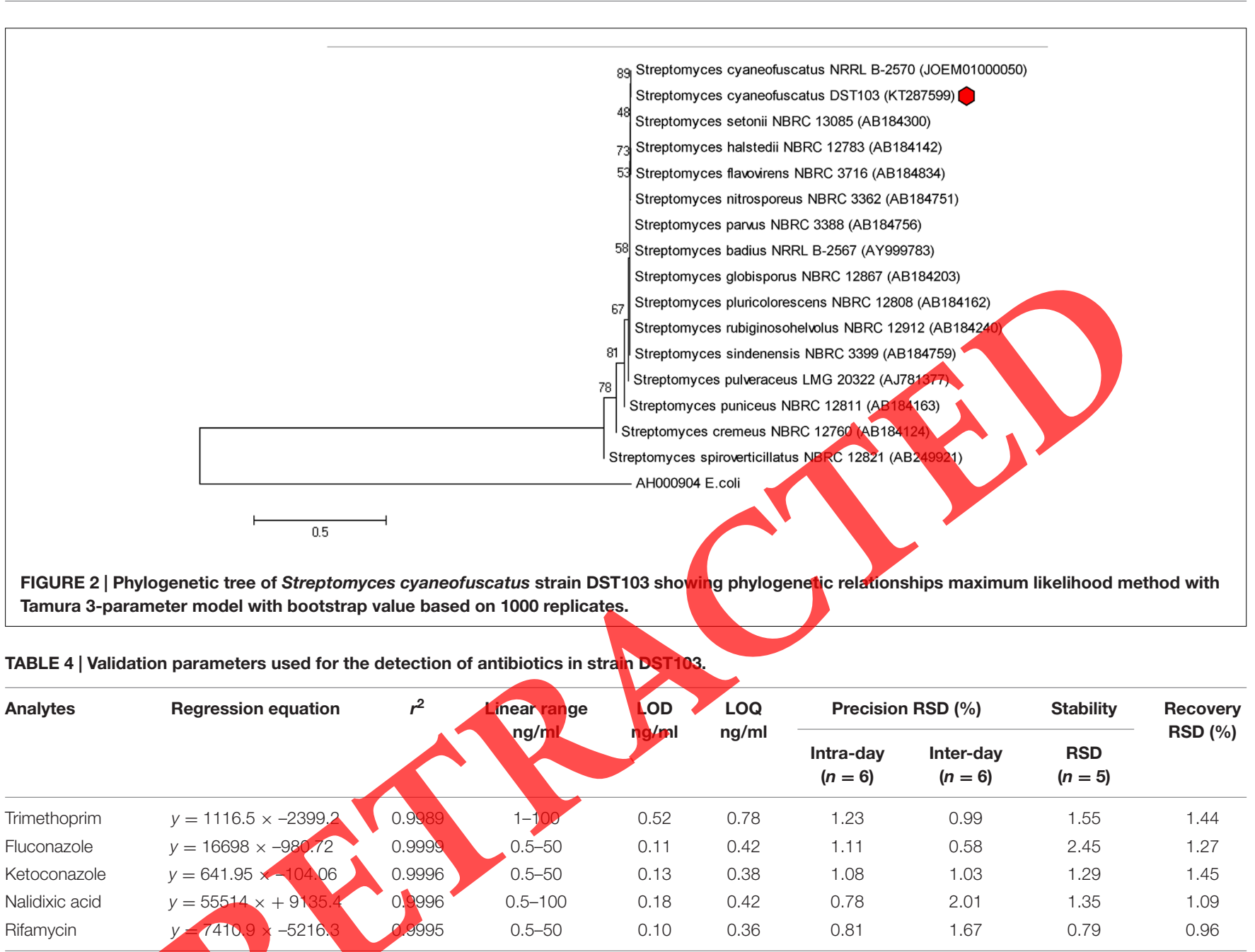

Transition/Transversion bias $(\mathrm{R})$ is 1.25 . The phylogenetic tree clearly showed that strain DST103 is closely related to Streptomyces cyaneofuscatus NRRL B-2570 ${ }^{\mathrm{T}}$, as they formed a distinct clade under a bootstrap support value of $89 \%$. The $16 \mathrm{~S}$ rRNA gene sequence analysis demonstrates that strain DST103 was intimately similar to the type strains Streptomyces setonii NBRC $13085^{\mathrm{T}}$ (99.85\% similarity) followed by Streptomyces halstedii NBRC $12783^{\mathrm{T}}$ (99.82\%), Streotomyces flavovirens NBRC $3716^{\mathrm{T}}$ (99.8\%) (Figure 2).

\section{Determination of MIC of Strain DST103}

The crude methanolic extract of strain DST103 exhibited strong antimicrobial activity against Gram positive bacteria, Gram negative bacteria and yeast pathogen. From our results, we observed that the isolate showed highest activity against E. coli (5.42 to $15.89 \mu \mathrm{g} / \mathrm{mL}$ ) followed by C. albicans (4.12 to $12.6 \mu \mathrm{g} / \mathrm{mL}$ ), B. subtilis (3.96 to $11.2 \mu \mathrm{g} / \mathrm{mL}$ ) and $P$. aeruginosa $(3.17$ to $8.0 \mu \mathrm{g} / \mathrm{mL})$, respectively. In 96 well plate assay, strain DST103 showed highest MIC values against E. coli $\left(\mathrm{EC}_{50}=2.1 \mu \mathrm{g} / \mathrm{mL}\right)$ whereas, lowest $\mathrm{MIC}$ values was recorded against $S$. aureus $\left(\mathrm{EC}_{50}=43.63 \mu \mathrm{g} / \mathrm{mL}\right)$. Standard known antibiotic ampicillin was used as positive control and 10\% DMSO solvent was used as negative control.

\section{Detection and Quantification of Antibiotics using UPLC-MRM Method Validation of Analytical Method}

As per the guidelines of international conference on harmonization ( $\left.\mathrm{ICH}, \mathrm{Q}_{2} \mathrm{R}_{1}\right)$ by linearity, solution stability, 


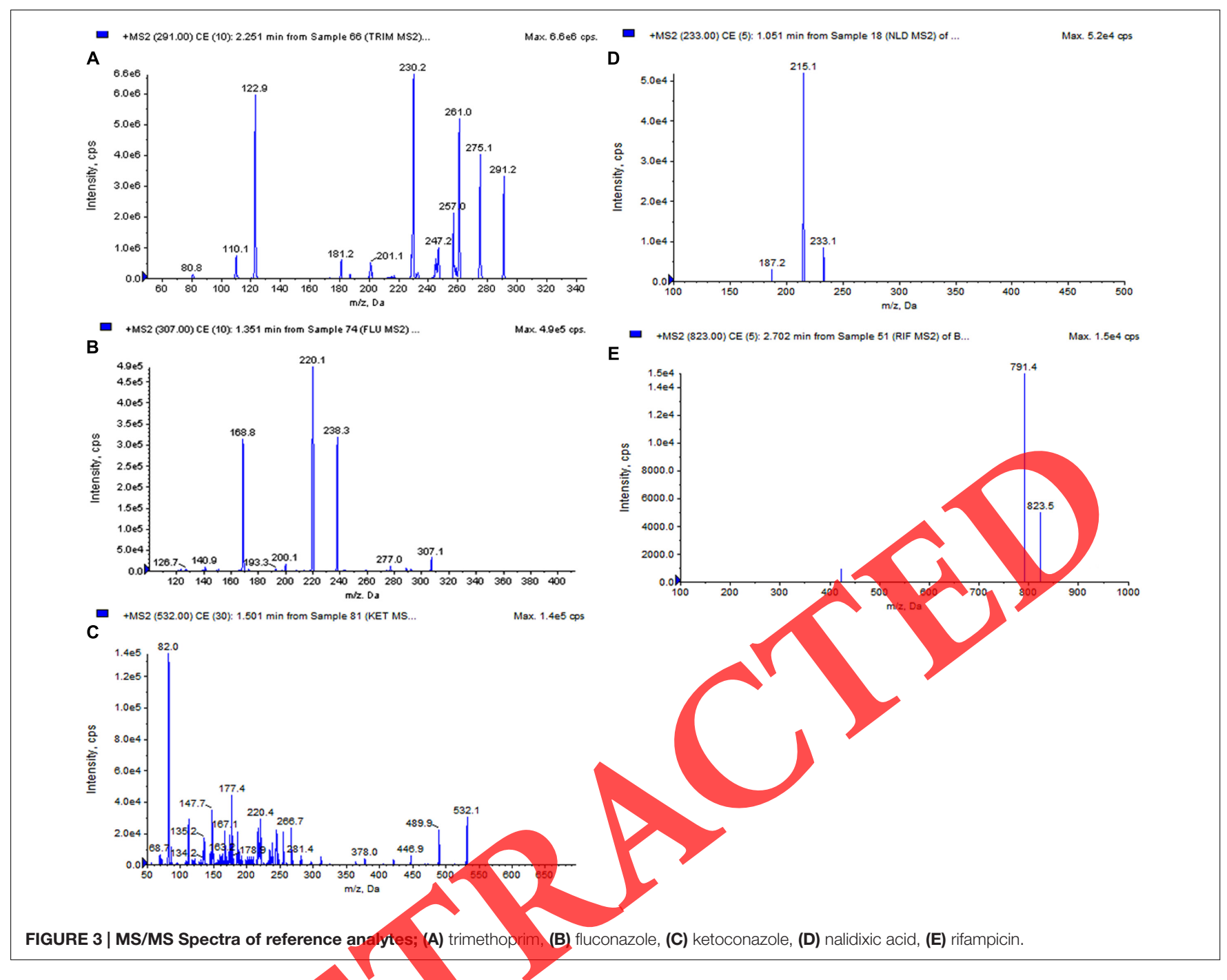

quantifications and limit of detections, precision and recovery, UPLC-MRM method was validated for quântitative analysis.

\section{Linearity, Limits of Detection (LOD) and Quantification (LOQ)}

A series of concentrations of standard solute ion were prepared for the establishing calibration curves. The peak areas were plotted against the corresponding concentrations to obtain the calibration curves. LOD and LOQ were determined by calibration curve method. LOD and LOQ were calculated by using following equations. $\mathrm{LOD}=(3.3 \times$ Sy.x $) / \mathrm{S} ; \mathrm{LOQ}=(10 \times$ Sy.x $) / \mathrm{S}$ (Where, Sy.x is standard deviation of residuals from line; $S$ is slope). The results were listed in Table 4. All the calibration curves indicated good linearity with correlation coefficients $\left(r^{2}\right)$ from 0.9989 to 0.9999 within the test ranges. The LOD and LOQ for each reference analyte were less than $0.52 \mathrm{ng} / \mathrm{mL}$ and $0.78 \mathrm{ng} / \mathrm{ml}$, respectively.

\section{Precision, Solution stability, and Recovery}

Relative standard deviation (RSD) was employed for precision evaluation. Analytes were determined in six replicates on a single day and by duplicating the experiments over three consecutive days to evaluate intra-day and inter-day variations. The overall precision was not more than $2.01 \%$. Sample solutions stability kept at room temperature was measured at $0,2,4,8,12$, and $24 \mathrm{~h}$ by replicate injections. The stability RSD value of analytes is $\leq 2.45 \%$. Recovery test was applied to evaluate the accuracy by spiking high, middle and lower concentration level of the analytical standards into the samples. Experiments were performed in triplicates at each level. The overall recovery of analytical method developed is in the range of $97.98 \%-102.12 \%$ $(\mathrm{RSD} \leq 1.45 \%)$ for all analytes which signifies a good accuracy (Table 4).

\section{Quantitative Analysis}

In this study UPLC-ESI-MS/MS method was used to quantify five standard antibiotics, i.e., trimethoprim, fluconazole, ketoconazole, nalidixic acid, and rifampicin in isolate DST103. Antibiotics like Nalidixic acid $(135.0 \mu \mathrm{g} / \mathrm{g})$ were present in highest amount followed by rifamycin $(56.0 \mu \mathrm{g} / \mathrm{g})$, ketoconazole (18.0 $\mu \mathrm{g} / \mathrm{g})$, trimethoprim $(18.0 \mu \mathrm{g} / \mathrm{g})$ while fluconazole 


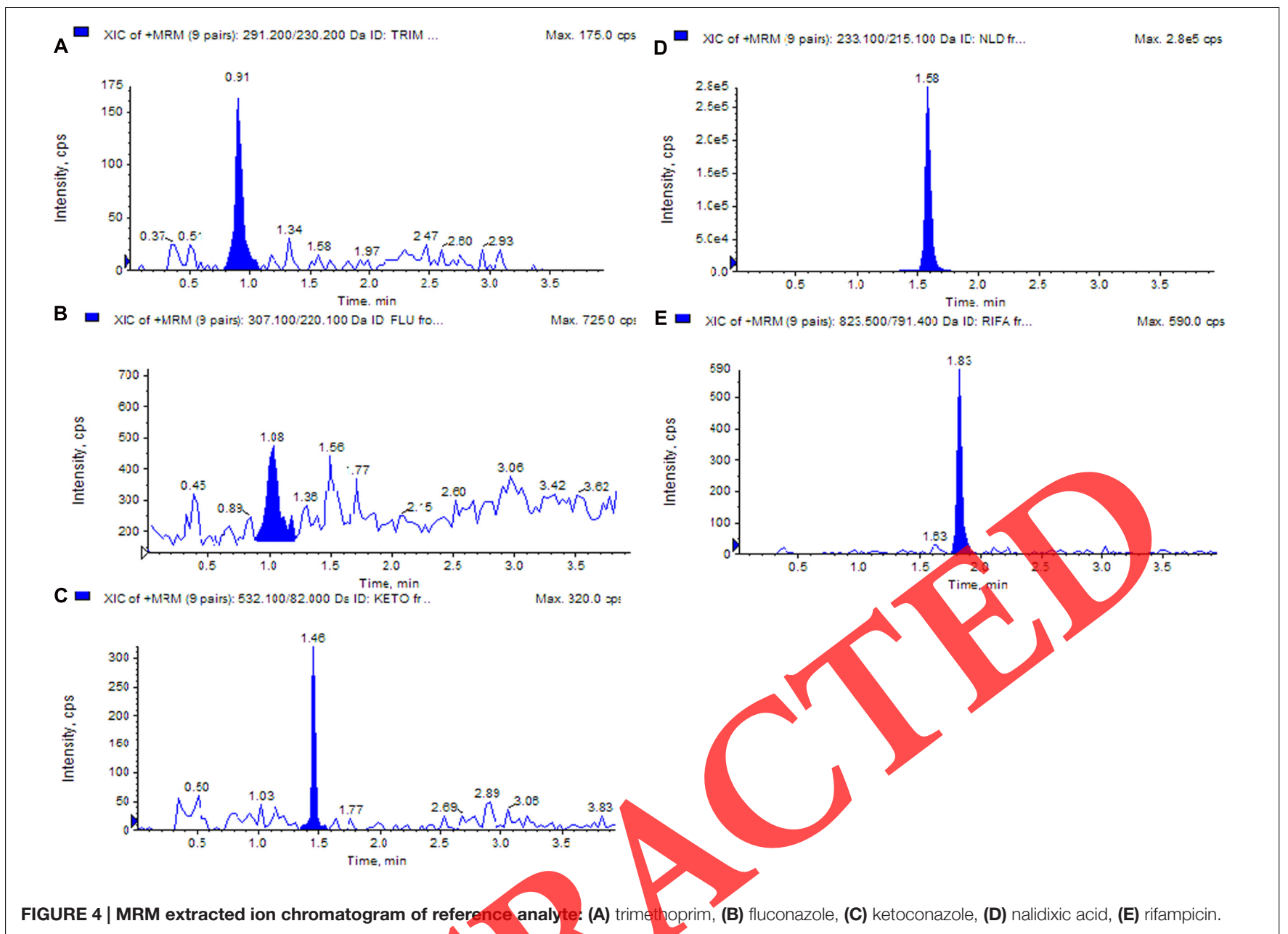

$(6.0 \mu \mathrm{g} / \mathrm{g})$ was lowest among all. MS spectra and MRM extraeted ion chromatogram of five standards and strain DST103 was shown in Figures 3 and 4, respectively.

\section{GC-MS Analysis of DST 103 Strain}

Methanolic extract of strain DST103 was analyzed using GCMS and identified four volatile compounds by comparison of their mass spectra with the NIST library based on their molecular weight, molecular formula, and retention time. The four compounds were (1) 2-propen-1-amine, n-2-propenyl-; (2) 2-propenal, 3-(1-aziridinyl)-3-(dimethylamino)-; (3) 2-decene, 3-methyl-, (z)-; (4) 5-pyrrolidino-2-pyrrolidone (Table 5). The peak area is directly proportional to the amount of compound present in the sample.

\section{Detection of PKS II, NRPS, and phzE Gene in DST103 Strain}

Biosynthetic potential genes encoding PKS type II, NRPS and aminodeoxyisochorismate synthase (phzE) were detected in DST103 strain, which may be responsible for the production of antimicrobial compounds. All the genes were sequenced and sequences were deposited in GenBank accession number
(KX595189 for PKSII, KX595190 for NRPS and KX894555 for $p h z \mathrm{E})$. PCR amplifications using degenerate primers showed the expected bands size of 600,700 , and $400 \mathrm{bp}$ for PKSII, NRPS and phzE genes, respectively (Figure 5).

\section{Phylogenetic Analysis Based on Biosynthetic Genes Sequences}

BLASTp analysis of the amino acid biosynthetic genes (PKSII, NRPS, and phzE) of strain DST103 revealed 63 to $100 \%$ identity with known type strains in the NCBI database. The maximum likelihood phylogenetic tree was constructed using the amino acid sequences of PKS type II gene showed that the strain DST103 was closely related to Streptomyces sp. SCAU5110 PKS type II (with sequence similarity of 78\%) and Streptomyces carnosus (ALP32528) PKS with bootstrap value of $64 \%$. In case of NRPS gene the strain DST103 was clustered with Streptomyces sp. 10-28-3A (BAH68821) with sequence similarity of $63 \%$ and Streptomyces lavendulae subsp. lavendulae (BAH68484) with sequence similarity of 61 with $77 \%$ of bootstrap supported values, respectively. The phzE gene sequences of strain DST103 was 100\% identical with Streptomyces sp. HB291 (Figure 6). 
TABLE 5 | Chemical compounds detected in strain DST103 by GC-MS analysis.

\begin{tabular}{|c|c|c|c|c|c|c|c|c|}
\hline SI No. & Compound name & $\begin{array}{l}\text { Retention } \\
\text { time (min) }\end{array}$ & Area (\%) & Formula & $\begin{array}{c}\text { Molecular } \\
\text { weight } \\
\text { (MW) }\end{array}$ & $\begin{array}{l}\text { Quality } \\
\text { (\%) }\end{array}$ & Activity & Reference \\
\hline 1 & $\begin{array}{l}\text { 2-propen-1-amine, } \\
\text { n-2-propenyl- }\end{array}$ & 17.545 & 8 & $\mathrm{C}_{6} \mathrm{H}_{11} \mathrm{~N}$ & 97 & 71 & Antibacterial & Senbagam et al., 2016 \\
\hline 2 & $\begin{array}{l}\text { 2-propenal, 3-(1-aziridinyl)- } \\
\text { 3-(dimethylamino)- }\end{array}$ & 17.820 & 8.96 & $\mathrm{C}_{7} \mathrm{H}_{12} \mathrm{ON}_{2}$ & 140 & 76 & Antimicrobial & Sheoran et al., 2015 \\
\hline 3 & 2-decene, 3-methyl-, (z)- & 18.995 & 30.00 & $\mathrm{C}_{11} \mathrm{H}_{22}$ & 154 & 78 & Antimicrobial & $\begin{array}{c}\text { Kalaiselvan et al., 2012; } \\
\text { Idramsa et al., } 2016\end{array}$ \\
\hline 4 & 5-pyrrolidino-2-pyrrolidone & 19.991 & 28.03 & $\mathrm{C}_{8} \mathrm{H}_{14} \mathrm{ON}_{2}$ & 154.209 & 74 & - & - \\
\hline
\end{tabular}

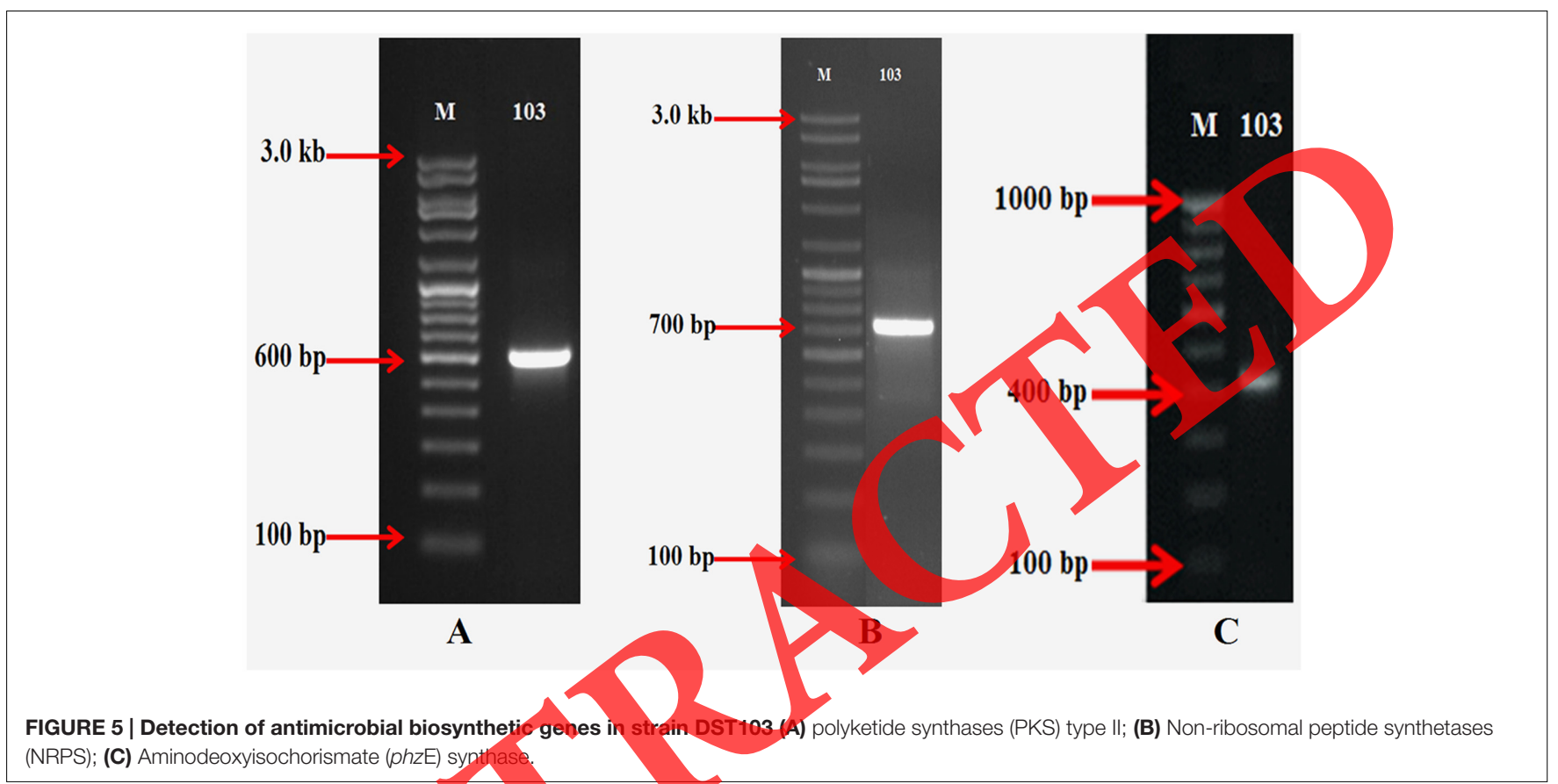

\section{DISCUSSION}

Secondary metabolites mainly new and novel antibiotics are in great demand with the increase in multi-drug resistant pathogens. A total of 50 actinobacteria were recovered in the present study using seven different media and among the media employed, SCA proved to be the best medium for isolation of fresh water actinobacteria supported by the findings of Rifaat (2003), Radhika et al. (2011), Zothanpuia et al. (2015). Preliminary screening of the isolates for their antimicrobial activities led to the selection of potential strain DST103 having strong activity against almost all the tested pathogens. The nature of colony of the strain was observed with hard and rough velvety texture on solid media with faint diffusible pigment. The strain showed optimum growth at $28^{\circ} \mathrm{C}$ on AIA, TSA, and SCA media. A slow growth was also observed on ISP2, AIA, SA, ISP5, and ISP7 media except TWYE medium which was also reported earlier by Passari et al. (2015).

Methanolic extract of the strain showed broad spectrum antimicrobial activity in secondary screening by agar well diffusion method which is in agreement with the finding of Gebreyohannes et al. (2013). It also exhibited good activity in 96 well plates inhibited the growth of pathogenic bacteria (E. coli, $S$. aureus, $P$. aeruginosa, and $B$. subtilis) and yeast pathogen C. albicans responsible for different food borne diseases. Strain DST103 showed positive activity against B. subtilis and $P$. aeruginosa with MIC values ranging from 3.96 to 11.2 and 3.17 to $8.0 \mu \mathrm{g} / \mathrm{mL}$, respectively. The strain DST103 exhibited highest antibacterial activity against E. coli $(5.42$ to $15.89 \mu \mathrm{g} / \mathrm{mL})$. Similar studies were reported by other researchers as well (Mukai et al., 2009; Kavitha et al., 2010; Atta, 2015; Sharma et al., 2016). This result showed that bioactive compounds having antimicrobial activities were extracellular and could be isolated and quantified that may help in the discovery of new drug (Passari et al., 2015). To best of our knowledge, this is the first report of $S$. cyaneofuscatus having strong antimicrobial activity against bacteria and yeast pathogens.

Results from 16S rRNA gene sequence and phylogenetic analyses revealed that the strain having strong antimicrobial properties was identified as Streptomyces cyaneofuscatus 

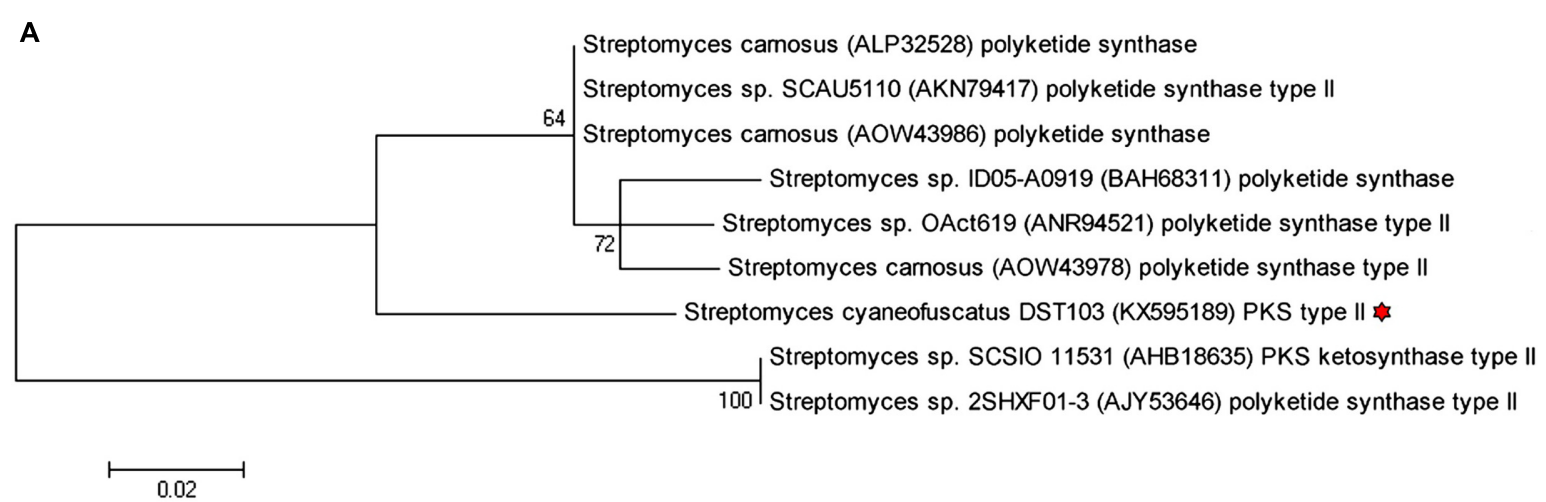

B

99 Streptamyces sp. 13-45-13 (BAH68826) NRPS gene

B Streptomyces sp. 16-45-C2 (BAH68829) NRPS gene
Streptomyces albidus (BAH68628) NRPS gene
Streptomyces microflavus (BAH68782) NRPS

Streptomyces nigrogriseolus (BAH68452) NRPS gene
Streptomyces carpaticus (BAH68698) NRPS gene

Streptomyces carpaticus (BAH68698) NRPS gene

77

Streptomyces lavendulae subsp. lavendulae (BAH68484)

100 Streptomyces sp. 10-28-3A (BAH68821) NRPS gene
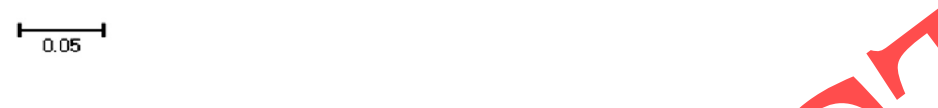

.

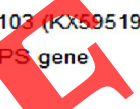

C

95

reptamyces sp. HB122 (AEJ87251) phzE gene

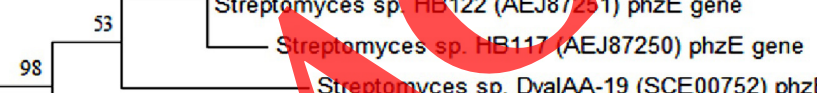

\begin{tabular}{|l|l|l|l} 
& \\
& Streptomyces sp. Scaelop-e83)(SCD78671) phzE gene
\end{tabular}

Streptomyces sp. LB129 (AEJ87256) phzE gene

75 Streptonyces sp. 13-2-21 (AJF94406) phzE gene
Streptomyces sp. 13-12-10 (AJF94402) phzE gene

0.05

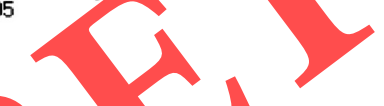

FIGURE 6 | Maximum likelihood (ML) phylogenetic tree constructed using amino acid sequences based on WAG model for PKS type II gene (A) and NRPS gene (B) and JT model for phzE gen (C). The scale bar represents the amino acid changes.

strain DST103 which was closely related to Streptomyces cyaneofuscatus NRRL B- $2570^{\mathrm{T}}$ with $99.87 \%$ sequence similarity. This is in agreement with results obtained by Hamedi and Papiran (2015). Streptomyces cyaneofuscatus M-27 having antitumor and anti-inflammatory compounds was also isolated from the Central Cantabrian Sea (Afredo et al., 2014).

The antibiotics content of the strain DST103 was quantified using UPLC-ESI-MS/MS method using five standard antibiotics, i.e., trimethoprim, fluconazole, ketoconazole, nalidixic acid and rifampicin. All the five antibiotics used in the study were detected and quantified, antibiotics like nalidixic acid and rifamycin were present with 135.0 and $56.0 \mu \mathrm{g} / \mathrm{g}$ respectively. This finding was similarly reported recently (Passari et al., 2016) that nalidixic acid and rifampicin was quantified with 0.951 and $0.017 \mathrm{mg} / \mathrm{g}$, respectively. The antibiotics content of the strain needs to be checked with more standard antibiotics for further investigation.

Gas chromatography-mass spectrometry is one of the most reliable techniques to identify the constituents of volatile compounds which were employed by a number of researchers (Jog et al., 2014; Tan et al., 2015; Sharma et al., 2016). The GC-MS chromatogram of the strain DST103 crude extract showed four major peaks with different retention time. Four volatile compounds were identified that were grouped into amine, ketones, aldehyde, and alkenes, which were renowned to have antimicrobial properties. Among them 2-decene, 3methyl-, (z)- an alkene group was detected in highest amount which alone constituted $30 \%$ of the total constituents present in 
DST103 which was also reported to have antimicrobial properties (Kalaiselvan et al., 2012; Idramsa et al., 2016). Other compounds like 2-propen-1-amine, $n$-2-propenyl- an amino group was also detected in strain DST103 which was reported to have antibacterial activity by Senbagam et al. (2016). 2-propenal, 3(1-aziridinyl)-3-(dimethylamino)- an aldehyde group was also detected and reported to have antimicrobial properties (Sheoran et al., 2015) but no reports has been found on 5-pyrrolidino2-pyrrolidone as an antimicrobial agent. The significance of this finding is that to best of our knowledge, all the above mentioned compounds have been detected for the first time from Streptomyces cyaneofuscatus or even from the phylum actinobacteria.

PCR detection and amplification of biosynthetic genes was crucial for assessing the biosynthetic potential of both culturable and non-culturable microorganisms (Minowa et al., 2007). NRPS, $\mathrm{PKS}$, and $p h z \mathrm{E}$ are biosynthetic systems responsible for the synthesis of a large number of biologically active compounds in actinobacteria and other microorganisms. NRPS and PKS are involved in the synthesis of bioactive peptides and polyketides and $p h z \mathrm{E}$ is involved in the synthesis of the antibiotic, phenazine, playing vital roles in biological control (Ayuso-Sacido and Genilloud, 2005; Yuan et al., 2014). In this study, NRPS, PKS II, and phzE gene sequences were detected in DST103 and amplified with the expected size which might be responsible for the regulation of its antimicrobial activity.

The present study revealed the presence of bioactive compounds in strain DST103, which could be a promising source for the discovery of novel bioactive metabolites against wide range of pathogens.

\section{REFERENCES}

Afredo, F. B., Fiedler, H. P., Nava, H., González, V., Sarmiento-Vizcaíno, A., Molina, A., et al. (2014). Two Streptomyces species producing antibiotic, antitumor, and anti-inflammatory compounds are widespread among intertidal macroalgae and deep-sea coral reef invertebrates from the central Cantabrian Sea. Microb. Ecol. 69, 512-524. doi: 10.1007/s00248-014-0508-0

Alvan, G., Edlund, C., and Heddini, A. (2011). The global need for effective antibiotics - A summary of plenary presentations Drug Resis. Updat. 14, 70-76. doi: 10.1016/j.drup.201 01.007

Atta, H. M. (2015). Biochemical studies on antibiotic production from Streptomyces sp.: taxonomy, fermentation, isolation and biological properties. J. Saudi Chem. Soc. 19, 12-22. doi: 10.1016/j.jscs.2011.12.011

Ayuso-Sacido, A., and Genilloud, O. (2005). New PCR primers for the screening of NRPS and PKS-I systems in actinomycetes: detection and distribution of these biosynthetic gene sequences in major taxonomic groups. Microb. Ecol. 49, 10-24. doi: 10.1007/s00248-004-0249-6

Berdy, J. (2005). Bioactive microbial metabolites. J. Antibiot. 58, 1-26. doi: 10.1038/ ja.2005.1

Das, S., Ward, L. R., and Burke, C. (2010). Screening of marine Streptomyces spp. for potential use as probiotics in aquaculture. Aquaculture 305, 32-41. doi: 10.1016/j.aquaculture.2010.04.001

David, B., Wolfender, J. L., and Dias, D. A. (2014). The pharmaceutical industry and natural products: historical status and new trends. Phytochem. Rev. 14, 299-315.

Edgar, R. C. (2004). MUSCLE: multiple sequence alignment with high accuracy and high throughput. Nucleic. Acids Res. 32, 1792-1797. doi: 10.1093/nar/gkh340

Eloff, J. N. (1998). Which extractant should be used for the screening and isolation of antimicrobial components from plants. J. Ethnopharmacol. 60, 1-8. doi: 10.1016/S0378-8741(97)00123-2

\section{AUTHOR CONTRIBUTIONS}

ZP: Complete the entire experiments and prepared the draft manuscript. AP, VL, and VM: Supported ZP to fulfill the experiment and also help in preparing the manuscript. $\mathrm{PC}, \mathrm{BK}$ : conducted HPLC analysis. BS: Experiment checked carefully, verified, and approved the final manuscript.

\section{ACKNOWLEDGMENTS}

BS is thankful to the Science and Engineering Research Board (SERB), Department of Science and Technology (DST), Government of India, New Delhi for funding as young scientist project No: SERB/F/2501/2013- 14. BS is also thankful to University Grants Commission (UGC), New Delhi for research funding as Major Research Project (69/2014 F.No10-11/12). Authors are also thankful to Department of Biotechnology, Ministry of Science and Technology, India, for establishment of the DBT-BIF Centre and the DBT-State Biotech Hub in the Department, which has been used for the present study. We are thankful to SAIF, NEHU for FEG SEM analysis and SAIF, CSIR-CDRI for conducting HRLC analysis.

\section{SUPPLEMENTARYMATERIAL}

The Supplementary Material for this article can be found online at: http.//journal.frontiersin.org/article/10.3389/fmicb. 2017.00068/full\#supplementary-material 2

Isenstein, J. (1985). Confidence limits of phylogenies: an approach using the bootstrap. Evolution 39, 783-791. doi: 10.2307/2408678

Gebreyohannes, G., Moges, F., Sahile, S., and Raja, N. (2013). Isolation and characterization of potential antibiotic producing actinomycetes from water and sediments of Lake Tana. Ethiopia. Asian Pac. J. Trop. Biomed. 3, 426-435. doi: 10.1016/S2221-1691(13)60092-1

Goodfellow, M., and Fiedler, H. P. (2010). A guide to successful bioprospecting: informed by actinobacterial systematics. Antonie Van Leeuwenhoek 98, 119-142. doi: 10.1007/s10482-010-9460-2

Goodfellow, M., and Haynes, J. A. (1984). "Actinomycetes in marine sediments," in Biological, Biochemical, and Biomedical Aspects of Actinomycetes, eds L. Ortiz-Ortiz, L. F. Bojalil, and V. Yakoleff (New York, NY: Academic Press), 453-472.

Goodfellow, M., and Williams, S. T. (1983). Ecology of actinomycetes. Annu. Rev. Microbiol. 37, 189-216. doi: 10.1146/annurev.mi.37.100183. 001201

Hamedi, J., and Papiran, R. (2015). Molecular characterization and periplasmic expression of the nlp gene of Streptomyces cyaneofuscatus UTMC 2101 in Escherichia coli. Ann. Microbiol. 65, 2047-2052. doi: 10.1007/s13213-015$1043-\mathrm{z}$

Idramsa, E., Sutariningsih, S., Laurentius, H. N., and Rarastoeti, P. (2016). Antimicrobial activities of endophytic bacteria isolated from Cotylelobium melanoxylon (hook.f.) pierre. Int. J. Pharm. Bio. Sci. 7, 666-672.

Jog, R., Pandya, M., Nareshkumar, G., and Rajkumar, S. (2014). Mechanism of phosphate solubilisation and antifungal activity of Streptomyces spp. Isolated from wheat roots and rhizosphere and their application in improving plant growth. Microbiology 160, 778-788. doi: 10.1099/mic.0. 074146-0 
Kalaiselvan, A., Gokulakrishnan, K., and Anand, T. (2012). Gas chromatography-mass spectrum analysis of bioactive components of the ethanol extract of Andrographis paniculata. J. Pharm. Biomed. Sci. 20.

Kavitha, A., Prabhakar, P., Narasimhulu, M., Vijayalakshmi, M., Venkateswarlu, Y., Rao, K. V., et al. (2010). Isolation, characterization and biological evaluation of bioactive metabolites from Nocardia levis MK-VL-113. Microbiol. Res. 165, 199-210. doi: 10.1016/j.micres.2009.05.002

Kim, K. J., Kim, M. A., and Jung, J. H. (2008). Antitumor and antioxidant activity of protocatechu aldehyde produced from Streptomyces lincolnensis M-20. Arch. Pharm. Res. 31, 1572-1577. doi: 10.1007/s12272-001-2153-7

Kim, T. U., Cho, S. H., Han, J. H., Shin, Y. M., Lee, H. B., and Kim, S. B. (2012). Diversity and physiological properties of root endophytic actinobacteria in native herbaceous plants of Korea. J. Microbiol. 50, 50-57. doi: 10.1007/s12275012-1417-x

Kuznetsov, S. I. (1970). Microflora of Lakes and its Geochemical Activity. Leningrad: Nauka.

Lazzarini, A., Cavaletti, L., Toppo, G., and Marinelli, F. (2000). Rare genera of actinomycetes as potential producers of new antibiotics. Antonie Van Leeuwenhoek 78, 399-405. doi: 10.1023/A:1010287600557

Minowa, Y., Araki, M., and Kanehisa, M. (2007). Comprehensive analysis of distinctive polyketide and nonribosomal peptide structural motifs encoded in microbial genomes. J. Mol. Biol. 368, 1500-1517. doi: 10.1016/j.jmb.2007.02.099

Mitra, A., Santra, S. C., and Mukherjee, J. (2008). Distribution of actinomycetes, their antagonistic behaviour and the physico chemical characteristics of the world's largest tidal mangrove forest. Appl. Microbiol. Biotechnol. 80, 685-695. doi: 10.1007/s00253-008-1626-8

Mukai, A., Fukai, T., Hoshino, Y., Yazawa, K., Harada, K., and Mikami, Y. (2009). Nocardithiocin, a novel thiopeptide antibiotic, produced by pathogenic Nocardia pseudobrasiliensis IFM 0757. J. Antibiot. 62, 613-619. doi: 10.1038/ja. 2009.90

Parungao, M. M., Maceda, E. B. G., and Villano, M. A. F. (2007). Screening of antibiotic producing actinomycetes from marine, brackish and terrestrial sediment of Samal Island, Philippines. J. Res. Sci. Comput. Eng. 4, 29-38.

Passari, A. K., Chandra, P., Zothanpuia, Mishra, V. K., Leo, V. V., Gupta, V. K, et al. (2016). Detection of biosynthetic gene and phytohormone production by endophytic actinobacteria associated with Solanum lycopersicum and their plant growth-promoting effect. Res. Microbiol. 167, 692-705. doi: 101016/j resmic. 2016.07.001

Passari, A. K., Mishra, V. K., Saikia, R., Gupta, V. K., a Isolation, abundance and phylogenetic affiliation of endophtic acti . (2015) associated with medicinal plants and screening for their in vitro antimicrobial biosynthetic potential. Front. Microbiol. 6:273. doi: 10.3389/fmicb.2015.00273

Procopio, R. E., De, L., Da Silva, I. R., Martins, M. K., De Azevedo, J. C., and De Araujo, J. M. (2012). Antibiotics produced by Streptomyces. Braz. J. Infect. Dis. 16, 466-471. doi: 10.1016/j.bjid.2012.08.014

Radhika, S., Bharathi, S., Radhakrishnan, M., and Balagurunathan, V. (2011). Bioprospecting of fresh water actinobacteria: isolation, antagonistic potential and characterization of selected isolates.). Pharm. Res. 4, 2584-2586.

Rajan, B. M., and Kannabiran, K (2014) Extraction and identification of antibacterial secondary metabolites from marine Streptomyces sp. VITBRK2. Int. J. Mol. Cell. Med. 3, 130-137.

Rifaat, H. M. (2003). The biodiversity of actinomycetes in the river nile exhibiting antifungal activity. J. Mediterr. Ecol. 4, 5-7.

Saadoun, I., and Muhana, A. (2008). Optimal production conditions, extraction, partial purification and characterization of inhibitory compound(s) produced by Streptomyces Ds-104 isolate against multi-drug resistant Candida albicans. Curr. Trends Biotechnol. Pharm. 2, 402-420.

Saitou, N., and Nei, M. (1987). The neighbor-joining method: a new method for reconstructing phylogenetic trees. Mol. Biol. Evol. 4, 406-425.

Saravanan, S., Sivakami, R., and Prem, G. K. (2015). Actinomycetes diversity in five fresh water systems of Pudukkottai, Tamilnadu and their antimicrobial activity. Int. J. Curr. Microbiol. App. Sci. 4, 672-677.

Saurav, K., and Kannabiran, K. (2012). Cytotoxicity and antioxidant activity of 5-(2, 4-dimethylbenzyl)pyrrolidin-2-one extracted from marine Streptomyces VITSVK5 spp. Saudi. J. Biol. Sci. 19, 81-86. doi: 10.1016/j.sjbs.2011.07.003

Schneemann, I., Wiese, J., Kunz, A. L., and Imhoff, J. F. (2011). Genetic approach for the fast discovery of phenazine producing bacteria. Mar. Drugs 9, 772-789. doi: $10.3390 / \mathrm{md} 9050772$
Senbagam, D., Senthilkumar, B., Amutha, R. A., Nagarajan, G., and Kalandar, A. (2016). Phytotherapeutic Control of Foodborne Pathogens by Jasminum sambac L. Flowers. The Authors Published by Innovare Academic Sciences Pvt Ltd. Available at: http://creativecommons.org/licenses/by/4.0/

Ser, H., Mutalib, A. B., Yin, N., Chan, K., Goh, B., and Lee, L. (2015). Evaluation of antioxidative and cytotoxic activities of Streptomyces pluripotens MUSC 137 isolated from mangrove soil in Malaysia. Front. Microbiol. 6:1398. doi: 10.3389/ fmicb.2015.01398

Sharma, P., Das, R., Kalita, M. C., and Thakur, D. (2014). Investigation of extracellular antifungal proteinaceous compound produced by Streptomyces sp. 5K10. Afr. J. Microbiol. Res. 8, 986-993. doi: 10.5897/AJMR2013. 6264

Sharma, P., Kalita, M. C., and Thakur, D. (2016). Broad spectrum antimicrobial activity of forest derived soil actinomycete, Nocardia sp. PB-52. Front. Microbiol. 7:347. doi: 10.3389/fmicb.2016.00347

Sheoran, N., Agisha, V. N., Vibhuti, M., Aditi, K., Kesavan, S., Vibina, V., et al. (2015). Genetic analysis of plant endophytic Pseudomonas putida BP25 and chemo-profiling of its antimicrobial volatile organic compounds. Microbiol. Res. 173, 66-78. doi: 10.1016/j.micres.2015. 02.001

Shirling, E. B., and Gottlieb, D. (1966). Mehods for characterization of Streptomyces species. Int. J. Syst. Bacteriol 16, 313-340. doi: 10.1099/0020771316-3-313

Sibanda, T., Mabinya, L. V., Mazomba, N., Akinpelu, D. A., Bernard, K., and Olaniran, A. O. (2010). Antibiotic producing potentials of three freshwater actinomycetes isolated from the eastern cape province of South Africa. Int. Mol. Sci. 11, 2612-2623. doi: 10.3390/ijms1107 2612

Stach, J. E. M., Maldonado, L. A., Ward, A. C., Goodfellow, M., and Bull, A. T. (2003). New primers specific for actinobacteria: application to marine and terrestrial environments. Environ. Microbiol. 5, 828-841. doi: 10.1046/j.14622920.2003.00483.x

Subramani, R., and Aalbersberg, W. (2012). Marine Actinomycetes: an ongoing source of novel bidactive metabolites. Microbiol. Res. 167, 571-580. doi: 10. 1016/j.micres.2012.06.005

Talukdar, M., Duarah, A., Talukdar, S., Gohain, M. B., Debnath, R., Yadav, A., et al. (2012). Bîoprospecting Micromonospora from Kaziranga National Park of India and heir anti-infective potential. World J. Microbiol. Biotechnol. 28, 2703-2712. doi: $10.1007 / \mathrm{s} 11274-012-1080-8$

Tamura, K., Peterson, D., Peterson, N., Stecher, G., Nei, M., and Kumar, S. (2011). MEGA5: molecular evolutionary genetics analysis using maximum likelihood, evolutionary distance, and maximum parsimony methods. Mol. Biol. Evol. 28, 2731-2739. doi: 10.1093/molbev/msr121

Tan, L. T. H., Ser, H. L., Yin, W. F., Chan, K. G., Lee, L. H., and Goh, B. H. (2015). Investigation of antioxidative and anticancer potentials of Streptomyces sp. MUM256 isolated from Malaysia mangrove soil. Front. Microbiol. 6:1316. doi: $10.3389 /$ fmicb.2015.01316

Thompson, J. D., Gibson, T. J., Plewniak, F., Jeanmougin, F., and Higgins, D. G. (1997). The Clustal X windows interface: flexible strategies for multiple sequence alignment aided by quality analysis tools. Nucleic Acids Res. 24, 4876-4882. doi: 10.1093/nar/25.24.4876

Wang, C., Wang, Z., Qiao, X., Li, Z., Li, F., Chen, M., et al. (2013). Antifungal activity of volatile organic compounds from Streptomyces alboflavus TD-1. FEMS Microbiol. Lett. 341, 45-51. doi: 10.1111/1574-6968. 12088

Wawrik, B., Kerkhof, L., Zylstra, G. J., and Kukor, J. J. (2005). Identification of unique type II polyketide synthase genes in soil. Appl. Environ. Microbiol. 71, 2232-2238. doi: 10.1128/AEM.71.5.2232-2238.2005

Weisburg, W. G., Barns, S. M., Pelletier, D. A., and Lane, D. J. (1991). 16S ribosomal DNA amplification for phylogenetic study. J. Bacteriol. 173, 697-703. doi: 10.1128/jb.173.2.697-703.1991

Yuan, M., Yu, Y., Li, H. R., Dong, N., and Zhang, X. H. (2014). Phylogenetic diversity and biological activity of actinobacteria isolated from the Chukchi Self marine sediments in the Arctic Ocean. Mar. Drugs 12, 1281. doi: 10.3390/ md12031281

Zothanpuia, P., Passari, A., and Singh, B. P. (2015). Molecular characterization of actinomycetes isolated from Tuichang river and their biosynthetic potential. Sci. Vis. 15:136. 
Zothanpuia, Passari, A. K., Gupta, V. K., and Singh, B. P. (2016). Detection of antibiotic-resistant bacteria endowed with antimicrobial activity from a freshwater lake and their phylogenetic affiliation. Peer J. 4:e2103. doi: 10.7717/ peerj. 2103

Conflict of Interest Statement: The authors declare that the research was conducted in the absence of any commercial or financial relationships that could be construed as a potential conflict of interest.
Copyright (c) 2017 Zothanpuia, Passari, Chandra, Leo, Mishra, Kumar and Singh. This is an open-access article distributed under the terms of the Creative Commons Attribution License (CC BY). The use, distribution or reproduction in other forums is permitted, provided the original author(s) or licensor are credited and that the original publication in this journal is cited, in accordance with accepted academic practice. No use, distribution or reproduction is permitted which does not comply with these terms.

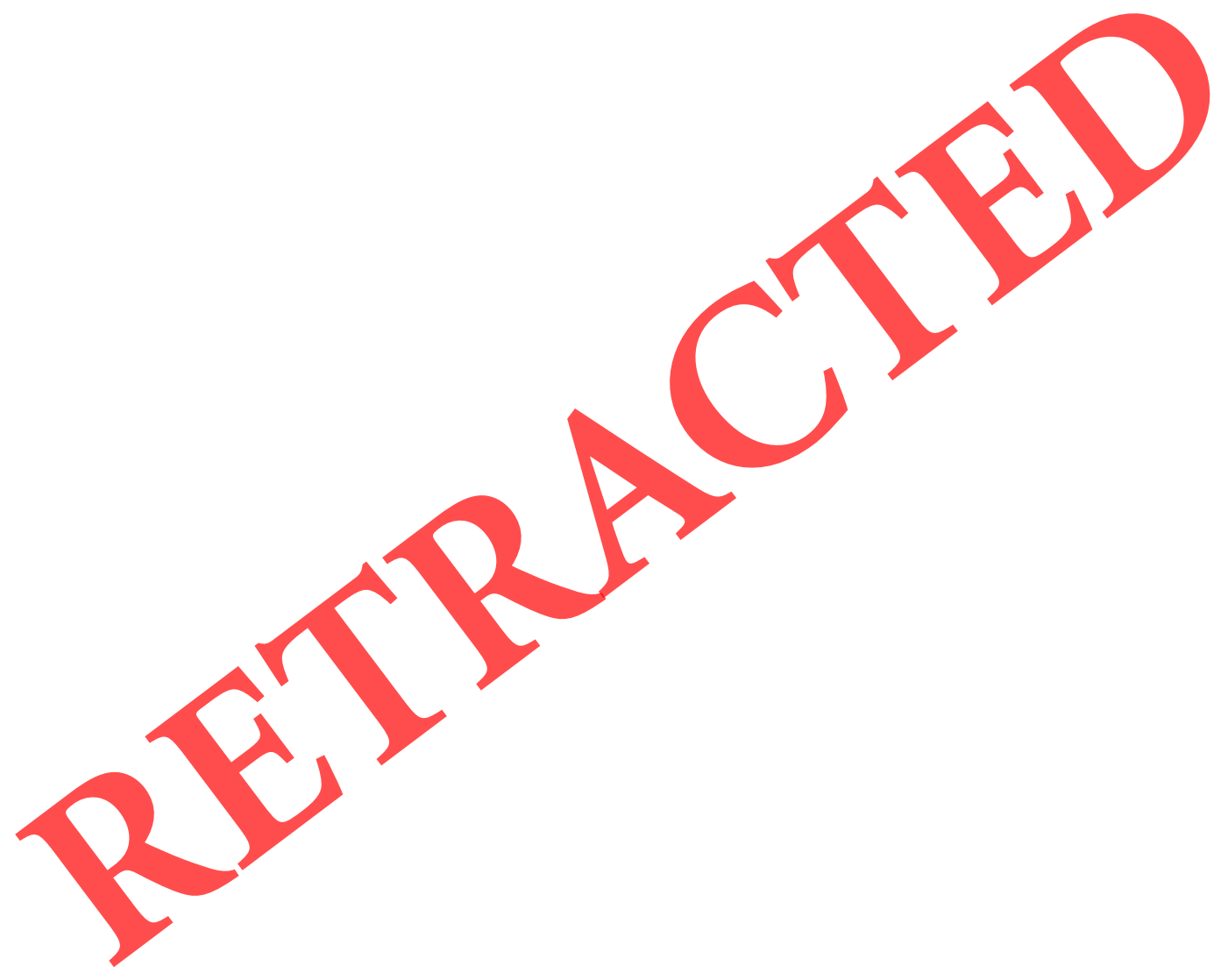

